\title{
Transparent Exopolymer Particles (TEP): an overlooked factor in the process of biofilm formation in aquatic environments.
}

\author{
Tom Berman \\ Yigal Alon Kinneret Limnological Laboratory, Israel Oceanographic and Limnological \\ Research, P.O.B 447, Migdal 14950, Israel \\ tberman@ocean.org.il \\ Uta Passow \\ Alfred Wegener Institute for Polar and Marine Research, 27570 Bremerhaven, Germany \\ Uta.Passow@awi.de
}

Key Words: Biofilm formation, TEP (Transparent exopolymer particles), natural/ anthropogenic aquatic environments. 


\begin{abstract}
We hypothesize that transparent exopolymer particles (TEP), present in high concentrations in most sea and freshwaters, are critical agents for biofilm initiation and development in many natural and anthropogenic aquatic environments. These gel-like particles appear in many forms; amorphous blobs, clouds, sheets, filaments or clumps ranging in size from $\sim 2$ to $\sim 200 \mu \mathrm{m}$. TEP are mostly polysaccharide, negatively charged, very sticky and are frequently colonized by bacteria. TEP may be considered a "planktonic" subgroup of exopolymeric substances (EPS), widely studied in biofilm research. Recognition of TEP involvement in biofilm formation has important implications for a comprehensive understanding of the complexities of this process in aquatic environments and may also contribute to the considerable efforts being made in the global water industry to mitigate the harmful effects of biofouling in water treatment and desalination plants.
\end{abstract}


In this paper we propose the concept that transparent exopolymer particles (TEP), ubiquitous in large numbers in both marine and freshwaters (Passow (2002), are an important but hitherto overlooked factor for the development of biofilms, both in natural and anthropogenic environments. The properties of these small ( 2 to $200 \mu \mathrm{m})$, negatively charged, mostly polysaccharide, gel-like particles strongly suggest their potential to play a key role in the initiation and growth of biofilm (Berman and Holenberg 2005).

\section{What is TEP?}

In 1993 Alldredge et al. reported a high abundance of previously undetected, transparent micro-particles in seawater that were visualized by staining with Alcian Blue, a dye specific for acid mucopolysaccharides. These were dubbed "Transparent Exopolymer Particles" or TEP. It quickly became evident that TEP are ubiquitous and numerous in most freshwater and marine environments and play important roles in these ecosystems. TEP range in size from $\sim 2 \mu \mathrm{m}$ to 100-200 $\mu \mathrm{m}$ and appear in many forms; amorphous blobs, clouds, sheets, filaments or clumps. Per definition, TEP are deformable, gel-like particles suspended in the water mass. This contrasts to the polysaccharide-containing biofilm matrix that adheres to substrate surfaces; however, TEP may be considered a "planktonic" subgroup of EPS [exopolymeric substances] .

The presence of highly surface active polysaccharides (Mopper et al. 1991) in TEP explains the strong tendency of these particles to form metal ion bridges and hydrogen bonds. As a result, TEP are usually extremely sticky with a high probability of attachment upon collision, about 2 to 4 orders of magnitude more sticky than phytoplankton or mineral particles (Passow 2002, Engel et al. 2004, Mari and Dam 2004). TEP are essential for the aggregation of particles in the open water, and for coating natural surfaces (Verdugo et al. 2004). In some aquatic environments, TEP appear to form abiotically from dissolved organic exudation products by processes of coagulation and gelation (Chin et al. 1998, Mari 1999, Passow 2000) or by bubble adsorption . Considerable amounts of TEP are also produced from the gelatinous envelopes surrounding diatoms and other algae (Passow \& Alldredge 1994) and from bacterial mucous (Stoderegger \& Herndl 1999). TEP may also be formed at senescence by algae and cyanobacteria (Grossart et al. 1997, Berman \& Viner-Mozzini 2001, Berman-Frank et al 2007) TEP have been termed "macrogels", and constitute a significant portion of the gel phase that forms an intermediate stage in the dissolved organic matter (DOM) to particulate organic matter (POM) continuum in seawater and freshwaters (Verdugo et al 2004).

In oceans and lakes, TEP are often colonized by bacteria and other microorganisms and serve as "hot spots", sites of intense microbial and chemical activity 
within the water mass . TEP may aggregate with each other or with other detrital fragments to form marine or lake "snow" (Logan et al. 1995, Grossard et al. 1997). Because TEP are rich in surface active acidic polysaccharides , many other substances, including proteins or trace elements can be associated with these gel-like particles. They adsorb trace metals (Niven et al. 1977, Santschi et al. 2006) and dissolved organic materials, thus providing favorable and specialized sites (e.g. low oxygen or anaerobic environments) for bacterial development. Additionally these particles, together with their associated flora and fauna, can serve as "food packages" for protists , microzooplankton and even larval fish (Grossart et al. 1998).

Some examples of TEP in near surface lake water are shown in Fig. 1. A comprehensive review of TEP in natural aquatic environments was published by Passow (2002).

\section{Applied aspects of biofilm formation}

Biofouling causes severe problems in environments as diverse as the ocean (fouling of ship hulls, coastal structures), industrial cooling towers and drinking water delivery systems. Minimizing biofilm development and accumulation is a major concern in desalination and water treatment industries (Flemming 1997, Kumar et al. 2006). The build-up of a biofilm layer due to microbial growth, deposition of colloidal matter and adsorption of organics on RO, NF and UF membrane surfaces leads to the deterioration of filtration efficiency and eventually the need to replace the membranes. Various strategies are used to mitigate biofilm formation by increasingly effective pretreatment of source waters (by fine filtration, UV irradiation etc) or by chemically modifying the membrane surfaces to inhibit microbial growth.

\section{TEP and biofilm formation}

Our hypothesis is that TEP play a key role in the initiation and outgrowth of biofilm on surfaces in the aquatic environment. Furthermore, we suggest that TEP are an important factor in causing biofilm development on the surfaces of filtration membranes increasingly used in desalination and water treatment plants. TEP may also be important in causing biofouling of a variety of infrastructure installations (water delivery pipes, cooling towers, etc)). 
Researchers of biofilm have long known that these layers consist of diverse populations of microorganisms, mostly bacteria, held together within a matrix of predominantly mucopolysaccharide, extracellular polymeric substances, EPS (Wigender et al. 1999). Almost all previous studies of biofilm initiation have concentrated on following the complex physical, chemical and biological interactions between biofilm forming bacteria such as Pseudomonas aeruginosa, Caulobacter crescentus, Legionella pneumophila (Strathmann et al. 2002, Encheva-Dimitrov and Sporman 2004, Kirisitis \& Parsek 2006, Lucas et al. 2006) and the substrate surface. Recently considerable attention has been given to the involvement of quorum sensing signaling and the nutritional status of the bacteria in promoting biofilm development (e.g. Rice et al. 2005, Kirisitis \& Parsek 2006) as well as to the important role of cell death and lysis (Bayles 2007) in this process. These studies indicate that successful adherence of bacterial cells to the substrate is a critical initial step for the establishment of the biofilm and assume that the nutrition fueling bacterial growth in biofilm derives from the dissolved organic matter of the overlying water.

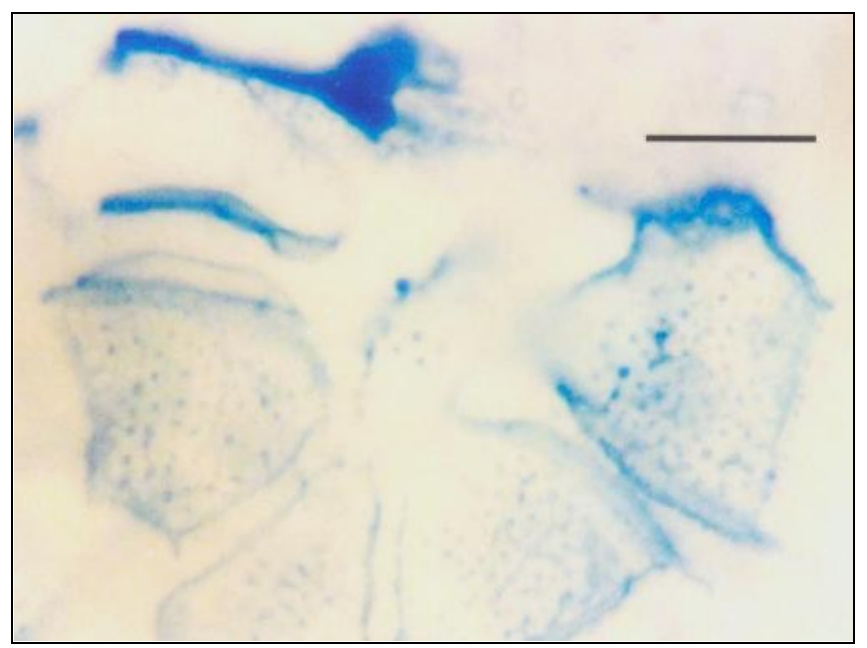


Fig. 1a

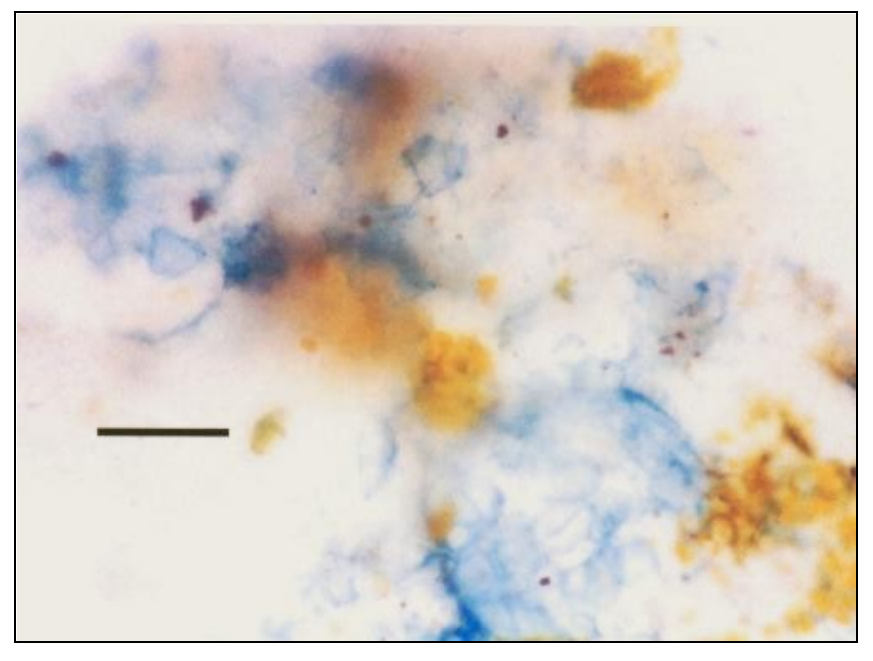

Fig. 1b 


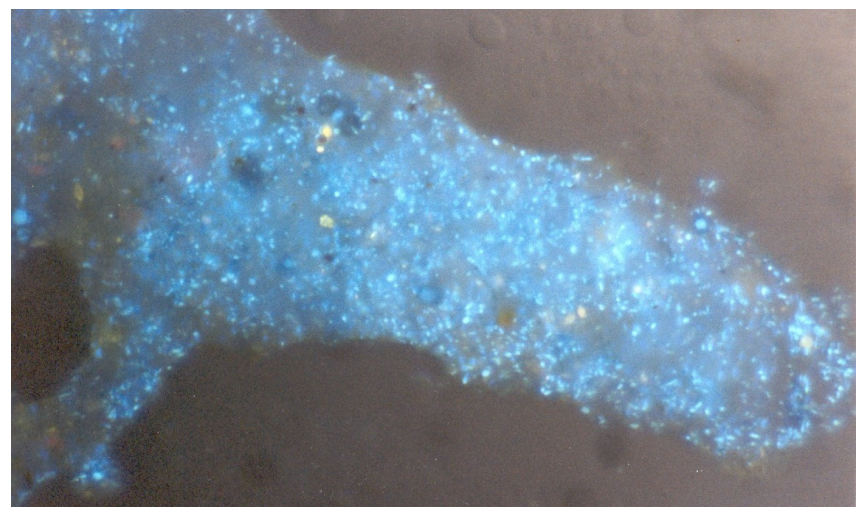

Fig 1c

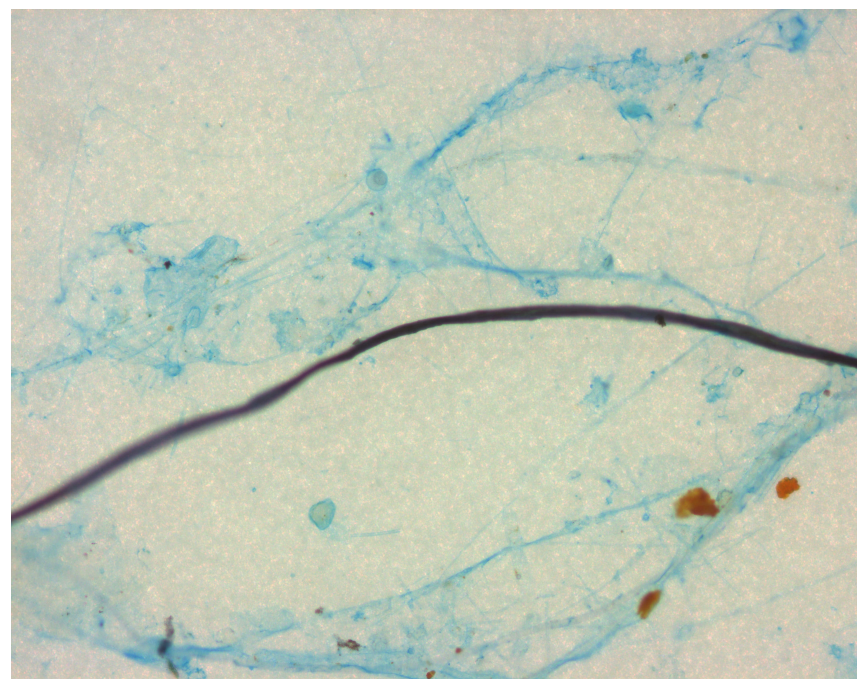

Fig 1d

Fig 1. Examples of TEP (stained blue): $a-c$, in a freshwater lake (Lake Kinneret): $d$. in the Southern Ocean

1a: TEP in detrital material from dinoflagellate algal bloom in spring. Bar $=5 \mu \mathrm{m}$

$1 b$ : TEP together with inorganic particles, summer. Bar $=20 \mu \mathrm{m}$

$1 c$ : TEP, with attached bacteria (combined DAPI and Alcian Blue stain).

(TEP abundance in this lake ranged from $4.4 \times 10^{5}$ to $2.5 \times 10^{7}$ particles $\mathrm{L}^{-1}$, Berman and Viner-Mozzini 2001). 
We suggest adding the involvement of TEP to previously described mechanisms for biofilm initiation and development on membranes and other surfaces. Most natural water sources have abundant levels of TEP and TEP precursors (Verdugo et al. 2004). Although concentrations of dissolved organic matter (DOM) tend to be high (> $1 \mathrm{mg} \mathrm{L}^{-1}$ ), usually only a small portion of this pool is readily available for the nutrition of microorganisms. We propose that, in aquatic environments, TEP are the major initiators of biofilm on both natural and man-made surfaces. TEP are small and sticky, and many of these particles are already colonized by bacteria. Once these particles adhere to a surface they provide a nutritious substrate for further microbial growth and establishment of biofilm. Possibly the microbial populations that eventually grow out in the biofilm are different from the "pioneers" arriving with the TEP. Development of the biofilm is further stimulated by the continuous stream of TEP arriving and being trapped at its surface. In Fig. 2 we show schematically how TEP in a flowing water mass might cause the build up of biofilm on a surface.

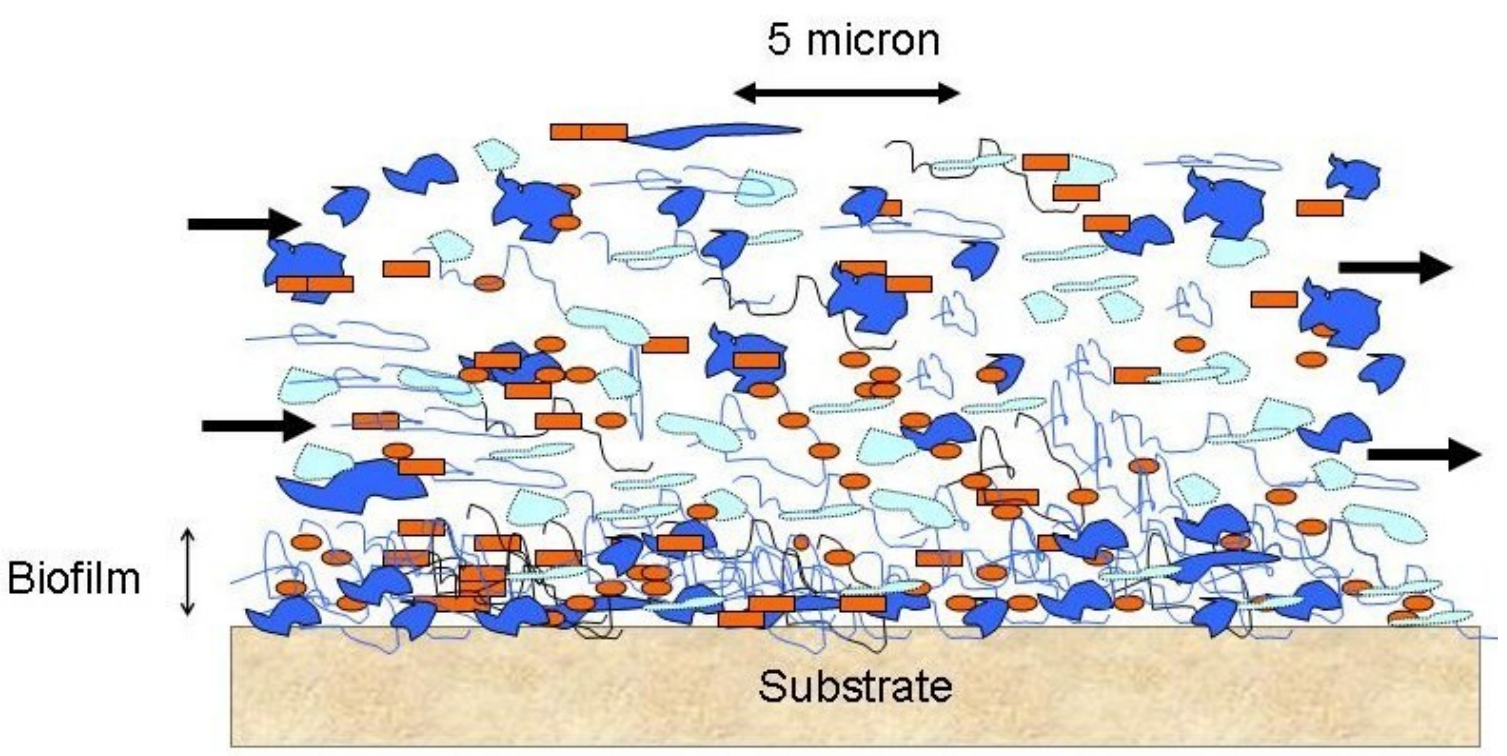

Fig 2. Schematic diagram of TEP involvement in biofilm development on a surface.

Initially a few TEP (dark blue), some with attached bacteria (red), stick to the pristine surface. Subsequently biofilm microorganisms (red) grow out. TEP provide a source of organic nutrition 
that can be easily hydrolyzed and absorbed by the bacteria growing on these particles. Other colloidal material (light blue) and additional TEP adhere to the surface and provide further nourishment for microorganisms. The developing biofilm organisms may also be able to exploit some of the dissolved organic matter such as dissolved amino acids and carbohydrates (thin dark blue squiggles) in the water stream (black arrows). Not shown are other biofilm forming processes taking place concomitantly. Modified from Berman and Holenberg, 2005. 
We emphasize this model does not exclude other known mechanisms of biofilm establishment and development that undoubtedly occur, such as individual cell attachment, quorum sensing, EPS proliferation, cell death and lysis. However, we submit that recognition and clarification of the role of TEP in biofilm formation are crucial to further understanding the complexities of this process. Furthermore, TEP involvement in biofilm development has important applicative implications for the considerable efforts being made in the global water industry to mitigate the harmful effects of biofouling in water treatment and desalination plants. 


\section{References}

Alldredge AL, Passow U, Logan BE (1993) The abundance and significance of a class of large, transparent organic particles in the ocean.

Deep-Sea Res. 40:1131-1140

Bayles KW. (2007) The biological role of death and lysis in biofilm development. Nature Reviews Microbiology 5: 721-725

Berman Y. Viner-Mozzini Y. (2001) Abundance and characteristics of polysaccharide and proteinaceous particles in Lake Kinneret. Aquatic Microb. Ecol. 24:255-264

Berman T, Holenberg M. (2005) Don't fall foul of biofilm through high TEP levels. Filtration + Separation. May 05: 30-32

Berman-Frank I, Rosenberg G, Levitan O, Haramaty L, Mari, X. (2007) Coupling between autocatalytic cell death and transparent exopolymeric particle production in the marine cyanobacterium Trichodesmium.

Environ. Microbiol. 9:1415-1422

Carrias J-F, Serre J-F, Sime-Ngando T, Amblard C. (2002) Distribution, size and bacterial colonization of pico- and nano-detrital organic particles in two lakes of different trophic status. Limnol. Oceanog. 47:1202-1209

Chin W, Orellana MW, Verdugo P (1998) Spontaneous assembly of marine dissolved organic matter into polymer gels. Nature 391:568-570.

Decho AW (1990) Microbial exopolymer secretions in ocean environments: Their role(s) in food web and marine processes.

Oceanography and Marine Biology Annual Review 28:73-153

Engel A, Thoms S, Riebesel U, Rochelle-Newall E, Zondervan I. Polysaccharide aggregation as a potential sink of marine dissolved organic carbon.

Nature 428: 929-932

Entcheva-Dimitrov P, Spormann A. (2004). Dynamics and Control of Biofilms of the Oligotrophic Bacterium Caulobacter crescentus. J. Bact. 186: 8254-8266

Flemming H-C (1997) Reverse Osmosis Membrane Fouling.

Exp. Thermal Fluid Science. 14:382-391

Grossart H-P, Simon M, Logan BE (1997) Formation of macroscopic organic aggregates (lake snow) in a large lake: the significance of transparent exopolymer particles (TEP), phyto- and zooplankton.

Limnol. Oceanogr. 42:1651-1659

Grossart H-P, Berman T, Simon M, Pohlmann P (1998) Occurrence and microbial dynamics of macroscopic organic aggregates (lake snow) in Lake Kinneret, Israel in fall. Aquat. Microb. Ecol. 14:59-67

Hoagland K, Rosowski J, Gretz M, Roemaer S (1993) Diatom extracellular polymeric substances: Function, fine structure, chemistry, and physiology.

Phycology 29:537-566 
Kirisitis MJ. Parsek MR. (2006) Does Pseudomonas aeruginosa use intercellular signalling to build biofilm communities? Cell Microbiol. 8:1841-1849.

Kumar M. Adham SS, Pearce WR. (2006) Investigation of Seawater Reverse Osmosis Fouling and Its Relationship to Pretreatment Type.

Environ.Sci. Technol. 40: 2037-2044

Lucas CE, Brown E, Fields BS. (2006) Type IV pili and type II secretion play a limited role in Legionella pneumophila biofilm colonization and retention Microbiol. 152: 3569-3573

Logan BE, Passow U, Alldredge AL, Grossart H-P, Simon M (1995) Rapid formation and sedimentation of large aggregates is predictable from coagulation rates (half-lives) of transparent exopolymer particles (TEP). Deep-Sea Res. 42:203-214

Mari X (1999) Carbon content and C:N ratio of transparent exopolymeric particles (TEP) produced by bubbling exudates of diatoms.

Mar. Ecol. Prog. Ser. 183:59-71

Mari X. Dam HG (2004) Production, concentration and isolation of transparent exopolymer particles using parmagnetid functionalized microspheres, Limnol. Oceanog. Methods. 2:13-24

Mari X, Rassoulzadegan F (2004) Role of TEP in the microbial food web structure. Grazing behavior of a bacterivorous pelagic ciliate. Marine Ecology Progress Series 279:13-22

Mopper K, Schultz C, Chevolot L, Germain C, Revuelta R, Dawson R (1991) Determination of sugars in unconcentrated seawater and other natural waters by liquid chromotography and pulsed amperometric detection. Envir.Science Tech. 26:133-149

Niven SEH, Kepkay PE, Bugden JBC (1997) The role of TEP in ${ }^{234}$ Th scavenging during a coastal bloom. Radioprotection-Colloques. 32:213-218

Passow U (2000) Formation of transparent exopolymer particles, TEP, from dissolved precursor material. Mar. Ecol. Prog. Ser. 192:1-11

Passow U. (2002) Transparent exopolymer particles (TEP) in aquatic environments. Progress in Oceanography. 55: 287-333.

Passow U, Alldredge AL (1994) Distribution, size and bacterial colonization of transparent exopolymer particles (TEP) in the ocean. Mar. Ecol. Prog. Ser. 113: 185-198

Passow U, Alldredge AL (1999) Do transparent exopolymer particles (TEP) inhibit grazing by the euphausid Euphausia pacifica? J. Plankton Res. 21:2203-2217

Rice SA, Koh S, Oueck SY, Labbate M, Lam KW, Kjelleberg S. (2005) Biofilm formation and sloughing in Serratia marcescens are controlled by quorum sensing and nutrient cues. J Bacteriol. 187(10):3477-85. 
Santschi PH, Murray JW, Baskaran M, Benitez-Nelson CR, Guo LD, Hung C-C, Lamborg C, Moran SB, Buesseler, KO, Passow U, Roy-Barman M (2006) Thorium speciation in seawater. Marine Chemistry 100: 213-236

Stoderegger KE, Herndl GJ (1999) Production of exopolymer particles by marine bacterioplankton under contrasting turbulence conditions.

Mar. Ecol. Prog. Ser. 189:9-16

Strathmann M., Wigender J, and Flemming H-C. (2002) Application of fluorescently labeled lectins for the visualization and biochemical characterization of polysaccharides in biofilms of Pseudomonas aeruginosa.

J. Microbiological Methods, 50: 237-248.

Wigender J., Neu T. R. and Flemming H-C. (1999). Microbial Extracellular Polymeric Substances. Springer. Berlin

Wotton R. (2004) The essential role of exopolymers (EPS) in aquatic systems Oceanography and Marine Biology: An Annual Review 42, 57-94

Verdugo P, Alldredge AL, Azam F, Kirchman D, Passow U, Santschi P (2004) The oceanic gel phase: a bridge in the DOM-POM continuum.

Marine Chemistry 92:67-85

Zhou J, Mopper K, Passow U (1998) The role of surface-active carbohydrates in the formation of transparent exopolymer particles by bubble adsorption of seawater. Limnol. Oceanogr. 43:1860-1871 